\title{
Latin America in the G20: Continuities and Ruptures of the Regional Agenda (2008-2018) ${ }^{1}$
}

\author{
C. Nahón
}

Cecilia Nahón - PhD, Executive Director of the American University Model G20 Initiative and former Ambassador of Argentina to the United States and G20 Sherpa of Argentina; US, Washington, DC 20016, 4400 Massachusetts Avenue, NW; E-mail: nahon@american.edu

\begin{abstract}
The Group of 20 (G20) broke onto the global scene shortly after the bankruptcy of the financial giant Lehman Brothers. The international financial system was crumbling from within and traditional policy tools were unable to stop the fall. The risks of global contagion were already being felt. Reflecting the emerging multipolar order, in particular the rise of China, President George W. Bush convened an urgent summit of the heads of state of the G20, a forum comprised by the main advanced and emerging economies, including the three largest Latin American countries (Argentina, Brazil and Mexico). Since 1999, the group had operated as a technical financial forum, but in November 2008 the first G20 leaders' summit took place in Washington, DC. In the decade that has passed since that first meeting, the leaders of the G20 have met a total of 12 times, and plan to do so again in November 2018 in Buenos Aires under the annual (rotating) G20 presidency of Argentina. This article explores the role and main contributions of the three Latin American economies in the G20 during the last decade, focusing in particular on the continuities and ruptures in the regional agenda and priorities towards the forum. With this goal in mind, the analysis begins with an overview of the metamorphosis of the G20 during the period 2008-2018. Then, the specific - and changing - Latin American path is explored. The article closes with a presentation of an alternative approach and agenda for the G20.
\end{abstract}

Key words: G20; agenda continuity; Latin America; Argentina; Mexico; Brazil

For citation: Nahón C. (2018) Latin America in the G20: Continuities and Ruptures of the Regional Agenda (2008-2018). International Organisations Research Journal, vol. 13, no 4, pp. 39-54 (in English). DOI: 10.17323/1996-7845-2018-04-02.

\section{Introduction}

The Group of 20 (G20) broke onto the global scene shortly after the bankruptcy of the financial giant Lehman Brothers, which until then had been the fourth-largest investment bank in the United States with a 158-year long history. On 15 September 2008, the world witnessed the unthinkable. The international financial system was crumbling from within and traditional policy tools were unable to stop the fall. Since mid-2007, the collapse of housing prices and the implosion of the subprime mortgage market bubble had generated a wave of bankruptcies in the financial sector in the United States and

${ }^{1}$ The editorial board received the article in May 2018. 
Europe. In October 2008, both the TED spread indicator, which accounts for the level of stress in the U.S. banking sector, and the Emerging Market Bond Index (EMBI) Global spread index, which reflects the combined risk of 61 emerging markets, reached their historic peaks [IMF, 2017]. The message was clear: the financial crisis was not easing and the risks of global contagion were already being felt.

It was then that President George W. Bush, in the final months of his second term, decided to convene a summit of the heads of state of the main global economies. Reflecting the emerging multipolar order, in particular the rise of China, Bush issued invitations to his peers among the G20. The exclusive Group of 7 (G7) at the table of global governance - comprised of the main advanced economies - was thus expanded to include the largest emerging economies as well. ${ }^{2}$ The G20 is comprised of nineteen national economies, plus the European Union, that are considered "systemically important" and that together account for more than $80 \%$ of global product, $75 \%$ of international trade and $66 \%$ of world population. Since 1999 , the group had operated as a technical forum for financial coordination between finance ministers, ${ }^{3}$ but in November 2008 the first G20 leaders' summit took place in Washington DC. The presidents of the three largest Latin American economies - Argentina, Brazil and Mexico - participated in this inaugural summit.

In the decade that has passed since that first meeting, the leaders of the G20 have met a total of 12 times, and plan to do so again in November 2018 in Buenos Aires under the annual (rotating) G20 presidency of Argentina. Previously, Mexico had hosted the leaders' summit in Los Cabos in 2012 and Brazil had served as the G20 coordinator in 2008 during the transition from a ministerial forum to forum for heads of state. This article explores the role and main contributions of the three Latin American economies in the G20 during the last decade, focusing in particular on the continuities and ruptures in the regional agenda towards the forum. With this goal in mind, the analysis begins with an overview of the metamorphosis of the G20 during its first decade. Then, the specific Latin American path is explored. The article closes with a brief presentation of an alternative approach and agenda for the G20.

\footnotetext{
${ }^{2}$ When the Emergency Economic Stabilization Act of 2008 was approved by the U.S. Senate, President Bush explained the rationale of the intervention to the American public: "By coming together on this legislation, we have acted boldly to help prevent the crisis on Wall Street from becoming a crisis in communities across our country. We have shown the world that the United States of America will stabilize our financial markets and maintain a leading role in the global economy [...] As a strong supporter of free enterprise, I believe government intervention should occur only when necessary. In this situation, action is clearly necessary" [The White House, 2008]. As soon as he took office in January 2009, President Obama doubled-down on the stimulus measures.

${ }^{3}$ Among the leaders who called for a new Bretton Woods were then Prime Minister Gordon Brown and then French President Nicolas Sarkozy.
} 


\section{A Decade of G20: From the Crisis Committee to the Committee Crisis}

\section{Crisis Committee (2008-2009)}

During the summits in Washington (2008), London (2009) and Pittsburgh (2009), the G20 functioned as a sort of "crisis committee;" leaders met to give the political signal that they would adopt exceptional measures to stabilize financial markets, contain the crisis and restore global growth. They promptly sealed a multilateral agreement to stimulate the large economies in a coordinated manner. The United States led this billion-dollar injection of resources through a combination of fiscal and monetary policies. Successive rescue and stimulus packages raised the fiscal deficit of the U.S. from $1.1 \%$ of gross domestic product (GDP) in 2007 to $9.8 \%$ in 2009, while the Federal Reserve cut its interest rate to historic levels and resorted to unconventional monetary policy (quantitative easing) to increase market liquidity. The European Central Bank also implemented expansive monetary policies and a majority of European Union members announced countercyclical fiscal policies.

Along with this Keynesian spirit, in their first joint statement G20 leaders reaffirmed their "shared belief" in "market principles" and "open trade and investment regimes," and also committed themselves to "avoid protectionism" [G20 Leaders' Declaration, 2008]. In addition, the leaders of the G20 recognized the need to introduce changes to the system: "we must lay the foundation for reform to help to ensure that a global crisis, such as this one, does not happen again." The truth is that the crisis was not only a financial bankruptcy, but also an intellectual one: according to mainstream economic theory - neoclassical economics - a crisis in the supposedly most perfect financial market in the world was simply inconceivable. The Independent Evaluation Office of the International Monetary Fund (IMF) recognized that the institution itself "did not anticipate the crisis, its timing, or its magnitude, and, therefore, could not have warned the membership" [IMF, 2011, p. 5]. The disorientation was high: shortly before the collapse of Lehman Brothers, the IMF authorities declared that the U.S. economy had avoided a hard landing (June 2008) and that the risks of a financial tail event had eased (July 2008).

In light of the failure of the institutions responsible for ensuring international financial and monetary stability, calls for founding a "new Bretton Woods" proliferated in the G20. But the impetus for transformation did not last long, and finally a more conservative perspective prevailed: the core of the reforms promoted by the G20 focused on strengthening international financial regulation, supervision, monitoring and coordination. Paradoxically, the IMF emerged from the crisis significantly strengthened. First, because it was capitalized with $\$ 750$ billion to expand its financial programmes, which remained under the same orthodox conditionality framework. Second, thanks to the leadership of the emerging countries, especially the BRICS grouping of Brazil, Russia, India, China and South Africa, the G20 agreed at the Seoul summit (2010) to 
implement a reform of IMF governance (quota distribution and voting power) to reflect the larger weight of emerging countries in the global economy, which eventually led to a more representative institution. ${ }^{4}$

\section{Main Forum for International Economic Cooperation (2010-2015)}

In 2009, the global economy experienced the most widespread and deepest economic contraction in decades $(-0.1 \%)$, dragged down by the collapse of the advanced economies (-3.4\%) [IMF, 2017]. The crisis quickly became known as the "Great Recession." But the demand stimulus programmes paid off, and in 2010 the developed economies recovered (3\%) and the global economy returned to a path of positive growth (5.4\%). The G20 leaders met again in Toronto in 2010 and celebrated the results achieved. At that summit they designated the G20 as the "premier forum for our international economic cooperation" and set the joint goal of achieving "strong, sustainable and balanced global growth." Even though the most acute phase of the financial implosion seemed to have passed, the crisis continued to hit hard on the real economy and was reflected in the vertiginous rise of unemployment, especially in advanced (European) countries and among young people. While emerging countries, and at some point the United States, advocated for continuing with demand stimulus policies, European countries - arguing the "lack of fiscal space" and the high debt levels in certain economies - pushed for the retraction of Keynesian programmes in favour of so-called "fiscal consolidation" (i.e., austerity and adjustment policies).

The decision by the G20 in 2010-2011 to reverse course and advocate for "fiscal consolidation" (including a reduced social budget) and "structural reforms" (including labour market deregulation), rather than continued support for recovery was a historic, procyclical mistake that contributed to the prolonged recession in the European Union and weak recovery elsewhere [Nahón, Polaski, 2017]. A certain early and extemporary complacency characterized the G20 communiqués, which celebrated several times the end of the crisis only to find it again shortly after. Indeed, the epicentre of the crisis moved from the United States to the eurozone, which fell into recession again in 2012 and experienced recurrent debt crises in the economies of the South European periphery (at this time the derogatory acronym PIIGS was coined, in reference to the fragile situations of Portugal, Ireland, Italy, Greece and Spain). Financial instability and the employment crisis turned out to be very persistent in Europe as a consequence of the early retraction of the stimulus programmes. By mid-2014, the fall in global demand and the effects of the U.S. Federal Reserve's quantitative easing program, together with the end of the upward cycle for commodities, were also having a negative impact on emerging countries, with lower Chinese growth rates and recessions in Brazil and Russia. However, even in this slowdown scenario, emerging countries - especially Asian

${ }^{4}$ Although IMF governance reform was agreed by the G20 in 2010, its implementation was postponed more than five years due to the delay in its approval by the United States Congress, whose legislative branch was the last among the G20 countries to ratify it. Such confirmation from the United States was essential to achieve $85 \%$ of the required votes in the IMF. 
economies - remained the driving force of the global economy, more than doubling the expansion rate of developed countries. ${ }^{5}$

As the crisis spread and its impact on labour and social issues deepened, the G20 also expanded its initial agenda to include issues such as employment, development, migration, climate change, energy and, forcibly, terrorism. On the one hand, the forum is weakened by the more general attacks on the multilateral system by the unilateral positions of President Donald J. Trump. In this phase, technical working groups and ministerial meetings proliferated. Meetings of G20 foreign ministers and ministers of agriculture, labour, energy and trade were organized in addition to the regular meetings (four to five a year) of the ministers of finance, central bank governors and sherpas. ${ }^{6}$ Increasingly, the margins of the summits became populated with bilateral and plurilateral meetings between the heads of state.

During the summits in Cannes (2011), St. Petersburg (2013) and, especially, Antalya (2015), the concern about persistent unemployment, wage stagnation and rising inequality gained momentum in the G20 agenda. The dynamic of the global economy had become one of unequal, fragile and moderate growth (below pre-crisis levels) which was clearly insufficient to revert labour market dynamics. The International Labour Organization (ILO) had estimated the job deficit in the world at 200 million. To make matters worse, the share of national income going to working people - the labour share - had been falling for decades in almost all G20 countries, especially in advanced countries, and the gap between workers' productivity and wages had widened [ILO, OECD, 2015]. The leaders then made calls for a more "inclusive" economy and the $\mathrm{G} 20$ developed a set of active policy recommendations to reverse these trends [G20, 2015]. However, these policies were ignored in practical terms by most G20 nations, wasting the opportunity to address the rising backlash against globalization [Polaski, 2017]. This lack of timely and appropriate action ended up paving the way, particularly in Europe and the United States, for the electoral triumphs of ultranationalist xenophobic candidates and proposals.

\section{Backlash Against Globalization and Committee Crisis (2016-2018)}

Just as the IMF did not anticipate the global crisis in 2008, the G20 did not foresee the 2016 anti-system electoral shockwaves on both sides of the North Atlantic. The Brexit and, successively, the U.S., British, French, German and Italian elections have revealed a massive rejection of the establishment. ${ }^{7}$ The liberal international order based on market principles and economic openness promoted by the G20 has been strongly

${ }^{5}$ In the 2011-2016 period, the advanced economies averaged an expansion of $1.7 \%$ while the emerging economies grew by an average of 5\% [IMF, 2017].

${ }^{6}$ The sherpas are the direct representatives of the heads of state in the G20 and have the function of coordinating the negotiations prior to the summits, ensuring consistency in the national positions of each country and focusing in particular on the non-financial agenda of the forum.

${ }^{7}$ The next paragraphs follow closely C. Nahón and S. Polaski [2017]. 
questioned. A decade after the outbreak of the crisis, the committee set up to deal with it itself went into crisis.

The G20 crisis is twofold. On the one hand, the forum is weakened by the more general pressure on the multilateral system which is undermined on a daily basis by the unilateral and threatening positions of President Donald J. Trump. In fact, at the last G20 summit in Hamburg, consensus was not reached on a key issue for the first time, and the final declaration ended up acknowledging the U.S. position on climate change separately from the other countries. Instead of G20 it was G1 + G19. Since then, American blows against the multilateral system have only escalated, as reflected in the failed G7 summit in June 2018, during which the U.S. president openly insulted the host, Prime Minister Justin Trudeau, and withdrew his country's support for the summit's carefully negotiated official communiqué. The U.S. unilateral imposition of $25 \%$ and $10 \%$ tariffs on steel and aluminum imports respectively also discredited the G20, which had been addressing the global steel oversupply through multilateral negotiations. Most recently, the U.S. imposition of duties on Chinese good valued at \$34 billion - openly violating World Trade Organization (WTO) rules - officially triggered the "largest trade war in economic history to date" involving the two major world economies and several G20 members which are already taking retaliatory measures.

But while Trump's statements and decisions are the most visible aspect of the crisis, the root cause of the tension is deeper: the G20's own principles and policy recommendations are being challenged by the recent anti-system revolts in developed countries. Globalization and financialization have always had winners and losers, but the accumulation of losers has mounted over the last decades, in some cases dramatically. According to Oxfam [2018], 82\% of the wealth generated in 2017 went to the richest $1 \%$ of the world's population, while the 3,700 million people who make up the poorest half of the world did not see an increase in their wealth. While the winners of globalization were promoting their recipes around the world, the losers were invisibilized and silenced. Over the last decade, the G20's agenda has been excessively influenced by the big financial institutions and multinational corporations. In the case of the United States, J. Stiglitz [2017] put it bluntly: "it was [a trade] agenda written by, and for, large multinational companies, at the expense of workers and ordinary citizens everywhere."

In this context, as the 2017 host country, Germany proposed to address "the fears and challenges associated with globalization," recognizing the need to offer a response to the ongoing backlash. However, the leaders' response at Hamburg was purely cosmetic, because the forum's policy orientation has not changed. It has been certainly positive that the group expressed with more emphasis the need for "inclusive" growth (this word appeared 15 times in the Hamburg declaration), that acknowledges rising inequality and that recognizes that "the benefits of globalization have not been shared enough." But these very commendable statements have not translated into consistent policies that favour a better distribution of income and wealth. In fact, in many G20 countries, as in Latin America, the current economic policies are significantly aggravating poverty and inequality. Beyond rhetoric, and despite recent conflicts among 
members, the heart of the G20 is still dominated by the old policies of liberalization, deregulation and fiscal consolidation that lie behind the globalization backlash.

\section{The Trajectory of Latin America in the G20: Continuities and Ruptures}

Throughout this decade, the role and agenda of the Latin American countries in the G20 has also been transformed. In a stylized manner, there are two distinct periods according to the political orientation of the governments of the region: a first phase, 2008-2015, marked by a majority of progressive and left-leaning governments, and a second phase, since 2016, corresponding to the return of conservative and right-leaning governments. ${ }^{8}$

\section{From Regional Integration to Competitive Fragmentation}

Both phases have in common the challenge to design and promote a common agenda at the G20 including the priorities of all three Latin American G20 members and, more generally, reflecting the interests of the entire region. However, there are striking differences in the dynamics of regional cooperation in the G20 between the two periods analyzed.

Between 2008 and 2015, Argentina and Brazil acted in the G20 as strategic allies, anticipating priorities, coordinating positions and amplifying their weight as Latin American voices. This was not by chance, but rather reflected the political decision of both countries to position regional integration as the pillar of their foreign policy. Indeed, during this period, key Latin American integration mechanisms were strengthened - like the MERCOSUR (South American Common Market) - and new bodies were founded - like the UNASUR (Union of South American Nations) created in 2004 and the CELAC (Community of Latin American and Caribbean States) founded in 2010 - and progress was being made at all levels of the G20. Argentina and Brazil formalized their G20 cooperation with the creation of a high-level bilateral committee that met and consulted regularly across the G20's agenda. However, this mechanism did not include Mexico. This was not due to lack of dialogue or camaraderie among the three countries, but rather a consequence of Mexico's strategic decision to align its positions in international economic and financial forums with the United States, its powerful northern neighbour and its main trading partner. Hence, the articulation with Mexico was more occasional and limited to specific issues of common interest. Notwithstanding this, the three Latin American countries participated actively in the informal coordination mechanism for emerging economies which met regularly after

${ }^{8}$ The first phase includes the governments of Cristina Kirchner in Argentina, first Lula da Silva and then Dilma Rousseff in Brazil, and Felipe Calderón and then Enrique Peña Nieto in Mexico. The second phase corresponds to the governments of Mauricio Macri, Michel Temer (who came to the presidency through an institutional coup in August 2016) and Enrique Peña Nieto, respectively. 
2010 to anticipate and articulate positions among the sherpas of certain emerging countries, including China, India, Indonesia, Russia and South Africa.

What is the situation today regarding Latin American coordination towards the G20? When inaugurating the Argentine G20 presidency on 1 December 2017, President Mauricio Macri stated: "We want to be the expression of an entire region, not only of our country" [2017]. This supposedly Latin American inclination was successively reiterated by high-level government officials, as well as by various analysts who advocate, rightfully, for the promotion of a Latin American agenda within the forum. However, it is not difficult to recognize that the president's wishful expressions are dissociated from his foreign policy. Since coming to power, the host of the next G20 summit has actively contributed to emptying the UNASUR, did not participate in any CELAC leaders' summit and has engaged with the MERCOSUR only as a platform to negotiate a free trade agreement with the European Union, the region that, together with the United States, is the beacon for Argentine foreign policy. Hence, the G20 presidency lands in Argentina at a moment of particularly weak regional integration and coordination, marked by fragmentation, competition and individual foreign policy strategies across the region. This dynamic is also reflected in integration schemes that are partial (Alliance of the Pacific, ALBA), ad-hoc (Group of Lima) or increasingly irrelevant (Summit of the Americas, Organization of American States).

Two decisions taken by Argentina during its G20 presidency also confirm its weak regional orientation. First, surprisingly, the date chosen for the Buenos Aires summit (30 November-1 December 2018) coincides with the presidential inauguration in Mexico, which has occurred every six years on 1 December since 1934. This conflict will significantly limit the participation of the Mexican president at the Buenos Aires summit. Second, Argentina decided to invite Chile and the Netherlands as guest countries, which contrasts with the Mexican invitation to two Latin American partners in 2012 (Chile and Colombia). ${ }^{9}$ Rightfully, Argentina has also invited the Caribbean Community to participate, which will be represented by Jamaica.

\section{From "Rule-Changer" to "Rule-Taker"}

Perhaps the most significant change between both phases is the turn, especially by Argentina and Brazil, away from a markedly critical and transformative position regarding the unfair rules of the international financial and trade system ("rule-changer") toward the passive acceptance of, and subordination to, those rules ("rule-taker").

Between 2008 and 2015, the countries of the Southern Cone promoted, through flexible coalitions with other blocs and/or G20 nations, a number of reforms of the global status quo. ${ }^{10}$ Since the Washington summit, and as a reflection of their own his-

${ }^{9}$ The invitation to the Netherlands at the expense of another Latin American country is hard to justify, particularly considering that the G20 already has over-representation of European countries (five countries plus the European Union).

${ }^{10}$ As L. Schweitzer [2016] points out, while Brazil adopted a more moderate position on this issue, Argentina opted for a stronger stance. 
tories, Argentina and Brazil advocated for countercyclical policies to face the Great Recession, a position also shared by the BRICS, with whom Brazil developed a growing level of coordination. Brazil, supported by Argentina, was also active in pushing for IMF governance reform. Latin American leaders were pioneers in advocating for the G20 to address international tax evasion and avoidance, calling for international cooperation to combat tax havens. ${ }^{11}$ The G20 committed to take action against tax havens for the first time at the London summit (2009), a push that eventually led to the adoption of the Organisation for Economic Co-operation and Development (OECD) BEPS (Base erosion and profit shifting) framework.

Another contribution from Argentina and Brazil questioning the status quo was their firm rejection in 2009 of "labour flexibilization" as a valid policy recommendation by the G20, calling instead for an early warning regarding the severe impact of the crisis on unemployment. This defensive position regarding labour issues was further enhanced by an offensive strategy to promote labour protection policies and social inclusion in the G20. Several results were achieved in this context, including the proposal to incorporate the ILO as a G20 partner on an equal footing with the IMF, the permanent quest to give voice to workers and labour unions - including the International Trade Union Confederation - in the G20, and the creation of a subgroup in 2015, co-chaired by Argentina and France, to analyze the role of inequality and income distribution as obstacles to sustainable growth. ${ }^{12}$ Both Argentina and Brazil also called firmly, together with other emerging countries, for the successful conclusion of the WTO Doha round according to its original development mandate and under the principle of "single undertaking." They also advocated for a truly balanced and fair multilateral trading system, guaranteeing developing countries their legitimate policy space for national development.

Finally, the issue of sovereign debt sustainability was raised early in the G20 by Argentina, with Brazilian support. Despite the persistent growth of debt-to-GDP ratios in the majority of G20 countries (especially the European ones), or perhaps precisely because of this, the issue faced notable resistance in the group, and it only entered the G20 at a relevant level at the St. Petersburg summit (2013) when leaders established that "events in recent years have shown the importance of debt sustainability for all." A year later, at the Brisbane summit (2014), after Argentina lost its emblematic debt case in the U.S. judicial system - which ruled in favour of highly aggressive holdouts - the G20 recognized "the challenges litigation poses" to the orderliness and predictability of the sovereign debt restructuring process and welcomed international work on strengthened collective action and pari passu clauses. It was a great diplomatic accomplishment for Argentina, which faced significant opposition from some G20 members, but which had the invaluable initial support of Brazil, Mexico, France, Australia, Russia and China. One year later, at the Antalya summit (2015), the relevance of the topic to the interna-

${ }^{11}$ According to the Economic Commission for Latin America and the Caribbean (ECLAC), total evasion implies a loss of public resources equivalent to 6.7\% of GDP in Latin America [CEPAL, 2017].

12 This work led to the document "G20 Policy Priorities on Labor Income Share and Inequalities" which was incorporated as an Annex to the 2015 Leaders’ Declaration. 
tional financial agenda was reaffirmed with a call for the IMF to continue encouraging the inclusion of such "anti-vulture" clauses in international sovereign bonds. ${ }^{13}$

\section{Towards the Buenos Aires Summit}

In contrast to their earlier stance, since 2016 Latin American leaders have positioned themselves in the G20 as mere "rule-takers" within the international financial and trade system, taking the view that it is convenient to accept things as they are instead of questioning or seeking to transform those international rules that are unfair or unfavourable to their strategic interests. The conception that lies behind Argentina's current foreign policy, crystallized in the relationship between Buenos Aires and Washington, is that "by making concessions to the powerful one's own interests are safeguarded" [Tokatlian, 2018]. In fact, it is paradoxical that Argentina assumes the presidency of the G20, which supposedly offers an opportunity to make its own contributions to the forum, precisely at a moment of particular weakness of this autonomous, national and Latin American vision. Latin American G20 countries, extremely fragmented, do not have a common agenda of their own to advance in the forum.

Clearly, Mauricio Macri imagined a very different international scenario (before Brexit and Trump) within which his country would head the G20: he aspired to preside over a Buenos Aires summit that would unanimously celebrate the liberal international order. Instead, today the Argentine presidency is forced to maneuver in a complex scenario marked by the crisis of multilateralism and the escalating disputes among G20 members (China, Mexico, Canada, the EU and Russia have already taken retaliatory trade measures against the U.S. for its unilateral imposition of border tariffs).

Against this background, the Argentine government has opted for a two-sided strategy. In its discourse, the Argentine G20 presidency puts forth a narrative of noble intentions, ambitious promises and politically correct phrases regarding its agenda and goals for the G20, pledging to "lead the G20 with the needs of the people in the forefront," "build consensus for an equitable and sustainable development," and direct a "G20 that contributes to the world and humanity." Conversely, on the substantive issues the Argentine presidency has proposed an agenda that is deliberately conservative, weak and with priorities that circumvent the most controversial - and most important - issues such as trade and climate change in order to satisfy the U.S. and ensure President Trump's participation.

Along this line, the three priorities proposed by Argentina for the G20 in 2018 are: "the future of work," "infrastructure for development" and "a sustainable food future." Beyond the bold titles, it is key to examine the content of the policies that are promoted in these priority areas. It would be harmful, for example, if the discussion on the role of new technologies and the future of employment was a Trojan horse to deliver labour deregulation and reduced employment protection, in line with the reform recently approved in Brazil and which the Argentine government intends to emulate at home.

${ }^{13}$ For a detailed review of the Argentine debt case and the G20, please see López and Nahón [2017]. 
Employment issues should not be addressed solely from a supply-side perspective (via training and education) at the risk of underestimating the role of demand-driven policies. In terms of infrastructure, the main topic seems to be the promotion and support of public-private partnerships (PPPs), a scheme cherished by the Macri government but which, under certain designs, could imply covert and dangerous mechanisms of indebtedness and/or privatization [Soler, 2018], as recently argued by 152 organizations from 45 countries in a public manifesto [Eurodad, 2017]. Finally, the theme of food security is well known in the G20 (it was one of Mexico's priorities in 2012) and the novelty this year relies on facilitating partnerships with the private sector within the general corporate approach of the Argentine presidency.

\section{An Alternative Agenda for the G20}

A decade after the first leaders' summit in Washington, the G20 arrives in South America weakened, questioned and fractured. Weakened, because the unilateral and threatening positions of U.S. President Donald Trump devalue daily the relevance and influence of the multilateral system built over the last seven decades. Questioned, because the anti-system electoral shockwaves on both sides of the North Atlantic have laid bare the strong rejection of the establishment and the principles of free markets and economic openness that have endured until now at the core of the G20. Fractured, because the escalating trade war openly antagonizes G20 members, eroding one of the main foundational commitments of the group (i.e., the standstill commitment to avoid protectionist measures).

In this critical moment, the role of leading the G20 far exceeds the capacity of the Argentine government, which remains trapped in its own downward economic spiral and whose inability to lead the group has already added uncertainty to a highly complex situation. Even Angela Merkel, chancellor of the fourth-largest economy in the world and the only leader of the G20 who has participated in all 12 summits of the forum, had a hard time leading the G20 to consensus during the German presidency.

Against this backdrop, prospects for the upcoming Buenos Aires summit are troubling. If most of the leaders insist on holding irreconcilable positions - some pushing against the previous status quo and Trump reaffirming his unilateral approach - the next G20 summit could end up in a new face-to-face confrontation, in tune with the failed G7 summit in Quebec. The Argentine host, faced with this prospect, has tried to minimize the controversial - but necessary - issues that confront members, to avoid in-depth discussions on the ongoing backlash against globalization and to promote progress on the (few) remaining areas of consensus. If it works, this conservative strategy could save the G20 facade, comply with the traditional family photo and even produce a leaders' declaration - as was the case in Hamburg last year - but it would be at the expense of the real weight and substance of the group, which will continue to lose significance.

To recover influence as the premier leaders' forum and serve ambitious goals regarding inclusive and sustainable growth, instead of insisting on the status quo the G20 
urgently requires a change of direction, an alternative paradigm that places sustainable development at the centre of its agenda. What would an alternative agenda consist of? A G20 focused on sustainable development would require the crafting of a new approach to multilateralism that directly serves people and national interests, recognizing that this would involve greater policy autonomy to design and implement inclusive domestic policies [Judis, 2017]. Failed policies of liberalization and "fiscal consolidation" should be abandoned in favour of policies that prioritize income and wealth redistribution, investment in infrastructure, industrial policy and scientific-technological development. It would also be necessary to reverse the current trend toward labour deregulation in favour of sensible regulations that restore workers' rights to organize and bargain, that guarantee decent employment and adequate minimum wages, and that reinforce social insurance systems. Recent research by the Economic Commission for Latin America and the Caribbean (ECLAC), the ILO and the IMF show that a better distribution of income makes growth more sustainable, as well as more fair.

For this approach to succeed, it is essential to build an adequate international financial architecture, so that cross-border capital flows are less volatile and destabilizing and serve to strengthen financing for development. Multilateral mechanisms that allow states to deal with sovereign debt in an orderly and fair manner should also be included in global financial agreements. In turn, the mantra of free trade should be replaced by trade policies that allow for the productive integration and complementation of national spaces, in keeping with the view that open trade and finance are not ends in themselves but are rather means for larger economic and social goals [Judis, 2017]. Of course, a fundamental issue for development is to recover state capacity and resources, for which it is imperative to give maximum importance to the fight against tax havens and international tax evasion and avoidance at both the domestic and international levels.

In short, the current multilateral crisis also offers an unforeseen historic opportunity: the chance to rebuild international cooperation with a focus on sustainable development, on the values of solidarity, democracy and equality among peoples. The G20 could choose to live up to this challenge and lead the way ahead. Time's up!

\section{References}

Comisión Económica para América Latina y el Caribe (CEPAL) (2017) CEPAL: Evasión fiscal alcanza los USD 340.000 millones en América Latina. Ekos, 2 October. Available at: https://www.ekosnegocios. com/negocios/m/verArticulo.aspx?idArt=9662 (accessed 11 October 2018) (in Spanish).

European Network on Debt and Development (Eurodad) (2017) World Bank Must Stop Promoting "Dangerous" Public-Private Partnerships. Available at: http://www.eurodad.org/PPPs-Manifesto (accessed 11 October 2018).

Group of 20 (G20) (2008) Leaders' Declaration. Washington DC, 15 November. Available at: http:// www.g20.utoronto.ca/2008/2008declaration1115.html (accessed 11 October 2018).

Group of 20 (G20) (2014) Leaders' Declaration. Brisbane, 16 November. Available at: http://www.g20. utoronto.ca/summits/2014brisbane.html (accessed 11 October 2018). 
Group of 20 (G20) (2015) G20 Policy Priorities on Labour Income Share and Inequalities. Annex I to the Leaders' Declaration of the G20. Antalya, 4 September. Available at: http://www.g20.utoronto.ca/2015/ G20-Policy-Priorities-on-Labour-Income-Share-and-Inequalities.pdf (accessed 11 October 2018).

Group of 20 (G20) (2017) Leaders' Declaration. Hamburg, 8 July. Available at: http://www.g20.utoronto. ca/2017/2017-G20-leaders-declaration.html (accessed 11 October 2018).

International Monetary Fund (IMF) (2017) World Economic Outlook Database, October 2017 Edition. Available at: https://www.imf.org/external/pubs/ft/weo/2017/02/weodata/index.aspx (accessed 11 October 2018).

International Monetary Fund (IMF) (2011) IMF Performance in the Run-Up to the Financial and Economic Crisis: IMF Surveillance in 2004-07. Evaluation Report, Independent Evaluation Office of the IMF. Available at: http://www.ieo-imf.org/ieo/files/completedevaluations/Crisis-\%20Main\%20Report\%20(without\%20Moises\%20Signature).pdf_(accessed 11 October 2018).

International Labour Organization (ILO), Organisation for Economic Co-operation and Development (OECD) (2015) The Labour Share in G20 Economies. Report prepared for the G20 Employment Working Group. Antalya, 26-27 February. Available at: https://www.oecd.org/g20/topics/employment-andsocial-policy/The-Labour-Share-in-G20-Economies.pdf (accessed 11 October 2018).

Judis J. (2017) What's Wrong with Our System of Global Trade and Finance? Interview with Dani Rodrik. TPM, 9 June. Available at: https://talkingpointsmemo.com/cafe/whats-wrong-system-global-tradefinance (accessed 11 October 2018).

Kharas H., Lombardi D. (2012) The Group of Twenty: Origins, Prospects and Challenges for Global Governance. Global Economic and Development Report, Brookings Institution, Washington DC. Available at: https://www.brookings.edu/research/the-group-of-twenty-origins-prospects-and-challengesfor-global-governance/ (accessed 11 October 2018).

Macri M. (2017) Palabras del Presidente Mauricio Macri en el lanzamiento de G20 Argentina 2018. G20 Argentina, 30 November. Available at: https://www.g20.org/es/prensa/sala-de-prensa/discursos/ palabras-del-presidente-mauricio-macri-en-el-lanzamiento-de-g20\# (accessed 11 October 2018) (in Spanish).

Nahón C., Polaski S. (2017) The G20's Future: Conflict, Irrelevance or Course Correction? Social Europe, 3 July. Available at: https://www.socialeurope.eu/g20s-future-conflict-irrelevance-course-correction (accessed 11 October 2018).

Oxfam (2018) Richest 1 Percent Bagged 82 Percent of Wealth Created Last Year - Poorest Half of Humanity Got Nothing. 22 January. Available at: https://www.oxfam.org/en/pressroom/pressreleases/2018-01-22/richest-1-percent-bagged-82-percent-wealth-created-last-year (accessed 11 October 2018).

Polaski S. (2017) Harnessing Macroeconomic, Social and Technology Policies to Create More and Better Jobs: Employment and Social Issues in the G20. Paper presented at the G20 and BRICS Cooperation for Resilient and Balanced Growth Conference, Moscow, 20 September.

Schweitzer L. (2016) The Trajectory of Argentina and Brazil in the G20 Between 2008 and 2015. Master in International Studies, Universidad Torcuato Di Tella, Buenos Aires.

Soler S. (2018) Negocios Públicos, Vicios Privados. El Cohete a la Luna. Available at: http://www.elcohetealaluna.com/negocios-publicos-vicios-privados/ (accessed 11 October 2018) (in Spanish).

Stiglitz J. (2017) Globalisation: Time to Look at Historic Mistakes to Plot the Future. The Guardian, 5 December. Available at: https://www.theguardian.com/business/2017/dec/05/globalisation-timelook-at-past-plot-the-future-joseph-stiglitz (accessed 11 October 2018).

The White House (2008) President Bush Discusses Emergency Economic Stabilization Act of 2008. 3 October. Available at: https://georgewbush-whitehouse.archives.gov/news/releases/2008/10/20081003-11. html (accessed 11 October 2018).

Tokatlian J.G. (2018) Relaciones con EE.UU: ¿Nueva Etapa? Diario Clarín, 2 February. Available at: https://www.clarin.com/opinion/relaciones-ee-uu-nueva-etapa_0_rka7ze-UM.html (accessed 11 October 2018) (in Spanish). 


\title{
Латинская Америка в «Группе двадцати»: преемственность и новые темы повестки (2008-2018 гг. $)^{1}$
}

\author{
C. $\mathrm{HaxOH}$
}

Нахон Сесилия - PhD, исполнительный директор, «Модель “Группы двадцати”, Американский университет; бывший посол Аргентины в США и шерпа Аргентины в «Группе двадцати»; US, Washington, DC 20016, 4400 Massachusetts Avenue, NW; E-mail: cnhon@gmail.com

«Группа двадиати» появилась на глобальной арене вскоре после банкротства финансового гиганта - банка Lehman Brothers, до того момента четвертого по величине инвестиционного банка в США, банка со 158-летней историей. 15 сентября 2008 г. случилось невообразимое. Международная финансовая система пошатнулась, а традиционные инструменты политики оказались не в состоянии остановить это падение. Начавшийся с середины 2007 г. резкий спад цен на жилье и «схлопывание» рынка субстандартной ипотеки привели к волне банкротств в финансовом секторе в США и странах Европы. В октябре 2008 г. и индикатор спред «ти-И-ди» (“ТЕD spread" indicator $)^{2}$, показывающий уровень стресса в банковском секторе США, и «глобальный индекс облигаций развивающихся стран» (“ЕMBI Global spread” index), показывающий уровень риска для 61 страны с переходной экономикой, достигли своих исторических максимумов [IMF, 2017]. Это означало, что финансовый кризис не ослаб, а, напротив, стал распространяться по всему миру.

Именно в тот момент президент США Джордж Буш-младший, второй президентский срок которого подходил к кониу, решил собрать саммит глав государств и правительств ключевых экономик мира. Выбор стран был обусловлен тенденциями формирования многостороннего миропорядка, в том числе возвышением Китая. Таким образом, «властители глобального управления» - клуб «Группы семи», объединяющий наиболее развитые экономики, был дополнен крупнейшими развивающимися странами . "Двадцатка», оббединивщая 19 стран и Европейский союз, рассматривалась как «системно значимый институт», на долю которого приходится более $80 \%$ глобального производства, 75\% - международной торговли и 66\% - мирового населения. С 1999 г. группа действовала как технический форум для координации министров финансов стран-участниих ${ }^{4}$, однако в ноябре 2008 г. состоялся первый саммит лидеров $G 20$ в Вашингтоне. В инаугурационном саммите приняли участие главы трех крупнейших латиноамериканских экономик - Аргентины, Бразилии и Мексики.

За десятилетие, прошедшее с саммита в Вашингтоне, лидеры стран - участнии «двадиатки» встретились в общей сложности 12 раз. Тринадиатый саммит состоится в ноябре 2018 г. в Буэнос-Айресе в ходе председательства Аргентины. До этого саммит лидеров G20 принимала Мексика (в Лос-Кабосе), а Бразилия выступала в качестве координатора «двадиатки» в 2008 г. в ходе перехода от формата встреч министров $\kappa$ формату встреч лидеров.

В данной статье исследуется роль и основной вклад трех латиноамериканских стран в деятельность «руппы двадиати» за последнее десятилетие. Автор, в частности, постарался проанализировать преемственность и новые темы в повестке G20, обусловленные региональными приоритетами. В начале статьи представлен обзор изменений, происходивших с G20 на протяжении первого десятилетия ее работы. Затем исследуется

\footnotetext{
${ }^{1}$ Статья поступила в редакцию в мае 2018 г.
}

${ }^{2}$ Разница между ставкой по казначейским векселям США и ставкой по евродолларам (Примеч. пер.).

3 «Группа двадцати» объединяет страны - члены «Группы семи» (Великобритания, Германия, Италия, Канада, США, Франция, Япония) + Европейский союз, Австралию и ряд стран с переходной экономикой: Аргентину, Бразилию, Индию, Индонезию, Китай, Мексику, Республику Корея, Россию, Саудовскую Аравию, Турцию и ЮАР. Испания является постоянной приглашенной страной. Также ежегодно страна-председатель выбирает другие приглашенные страны в соответствии со своими региональными приоритетами.

${ }^{4}$ Первая встреча «Группы двадцати» состоялась в Берлине в 1999 г. по инициативе министра финансов США Ларри Саммерса и министра финансов Канады Пола Мартина, которые отобрали участников, исходя из их значимости для мировой экономики, а также стремления обеспечить определенный региональный баланс, что, безусловно, не могло исключить определенного самоволия [Kharas and Lombardi, 2012]. 
вклад латиноамериканских стран в работу данного института. Завершается статья кратким представлением альтернативного подхода и повестки для «двадцатки».

Ключевые слова: «Группа двадцати»; преемственность повестки

Для цитирования: Нахон С. (2018) Латинская Америка в «Группе двадцати»: преемственность и новые темы повестки (2008-2018 гг.). Вестник международных организаций. Т. 13. № 4. С. 39-54 (на русском и английском языках). DOI: 10.17323/1996-7845-2018-04-02.

\section{Источники}

Comisión Económica para América Latina y el Caribe (CEPAL) (2017) CEPAL: Evasión fiscal alcanza los USD 340.000 millones en América Latina // Ekos. 2 October. Режим доступа: https://www.ekosnegocios. com/negocios/m/verArticulo.aspx?idArt=9662 (дата обращения: 11.10.2018).

European Network on Debt and Development (Eurodad) (2017) World Bank Must Stop Promoting "Dangerous” Public-Private Partnerships. Режим доступа: http://www.eurodad.org/PPPs-Manifesto (дата обращения: 11.10.2018).

Group of 20 (G20) (2008) Leaders' Declaration. Washington DC, 15 November. Режим доступа: http://www. g20.utoronto.ca/2008/2008declaration1115.html (дата обращения: 11.10.2018).

Group of 20 (G20) (2014) Leaders' Declaration. Brisbane, 16 November. Режим доступа: http://www.g20. utoronto.ca/summits/2014brisbane.html (дата обращения: 11.10.2018).

Group of 20 (G20) (2015) G20 Policy Priorities on Labour Income Share and Inequalities. Annex I to the Leaders' Declaration of the G20. Antalya, 4 September. Режим доступа: http://www.g20.utoronto.ca/2015/ G20-Policy-Priorities-on-Labour-Income-Share-and-Inequalities.pdf (дата обращения: 11.10.2018).

Group of 20 (G20) (2017) Leaders' Declaration. Hamburg, 8 July. Режим доступа: http://www.g20.utoronto. ca/2017/2017-G20-leaders-declaration.html (дата обращения: 11.10.2018).

International Monetary Fund (IMF) (2017) World Economic Outlook Database, October 2017 Edition. Peжим доступа: https://www.imf.org/external/pubs/ft/weo/2017/02/weodata/index.aspx (дата обращения: 11.10.2018)

International Monetary Fund (IMF) (2011) IMF Performance in the Run-Up to the Financial and Economic Crisis: IMF Surveillance in 2004-07. Evaluation Report, Independent Evaluation Office of the IMF. Режим доступа: http://www.ieo-imf.org/ieo/files/completedevaluations/Crisis-\%20Main\%20Report\%20(without\%20Moises\%20Signature).pdf (дата обращения: 11.10.2018).

International Labour Organization (ILO), Organisation for Economic Co-operation and Development (OECD) (2015) The Labour Share in G20 Economies. Report prepared for the G20 Employment Working Group. Antalya, 26-27 February. Режим доступа: https://www.oecd.org/g20/topics/employment-and-social-policy/The-Labour-Share-in-G20-Economies.pdf (дата обращения: 11.10.2018).

Judis J. (2017) What's Wrong with Our System of Global Trade and Finance? Interview with Dani Rodrik. TPM, 9 June. Режим доступа: https://talkingpointsmemo.com/cafe/whats-wrong-system-global-trade-finance (дата обращения: 11.10.2018).

Kharas H., Lombardi D. (2012) The Group of Twenty: Origins, Prospects and Challenges for Global Governance. Global Economic and Development Report, Brookings Institution, Washington DC. Режим доступа: https://www.brookings.edu/research/the-group-of-twenty-origins-prospects-and-challenges-for-global-governance/ (дата обращения: 11.10.2018).

Macri M. (2017) Palabras del Presidente Mauricio Macri en el lanzamiento de G20 Argentina 2018. G20 Argentina, 30 November. Режим доступа: https://www.g20.org/es/prensa/sala-de-prensa/discursos/palabrasdel-presidente-mauricio-macri-en-el-lanzamiento-de-g20\# (дата обращения: 11.10.2018).

Nahón C., Polaski S. (2017) The G20's Future: Conflict, Irrelevance or Course Correction? // Social Europe. 3 July. Режим доступа: https://www.socialeurope.eu/g20s-future-conflict-irrelevance-course-correction (дата обращения: 11.10.2018). 
Oxfam (2018) Richest 1 Percent Bagged 82 Percent of Wealth Created Last Year - Poorest Half of Humanity Got Nothing. 22 January. Режим доступа: https://www.oxfam.org/en/pressroom/pressreleases/2018-01-22/ richest-1-percent-bagged-82-percent-wealth-created-last-year (дата обращения: 11.10.2018).

Polaski S. (2017) Harnessing Macroeconomic, Social and Technology Policies to Create More and Better Jobs: Employment and Social Issues in the G20. Paper presented at the G20 and BRICS Cooperation for Resilient and Balanced Growth Conference, Moscow, 20 September.

Schweitzer L. (2016) The Trajectory of Argentina and Brazil in the G20 Between 2008 and 2015. Master in International Studies, Universidad Torcuato Di Tella, Buenos Aires.

Soler S. (2018) Negocios Públicos, Vicios Privados // El Cohete a la Luna. Режим доступа: http://www.elcohetealaluna.com/negocios-publicos-vicios-privados/ (дата обращения: 11.10. 2018).

Stiglitz J. (2017) Globalisation: Time to Look at Historic Mistakes to Plot the Future // The Guardian. 5 December. Режим доступа: https://www.theguardian.com/business/2017/dec/05/globalisation-time-lookat-past-plot-the-future-joseph-stiglitz (дата обращения: 11.10. 2018).

The White House (2008) President Bush Discusses Emergency Economic Stabilization Act of 2008. 3 October. Режим доступа: https://georgewbush-whitehouse.archives.gov/news/releases/2008/10/20081003-11.html (дата обращения: 11.10. 2018).

Tokatlian J. G. (2018) Relaciones con EE.UU: ¿Nueva Etapa? // Diario Clarín. 2 February. Режим доступа: https://www.clarin.com/opinion/relaciones-ee-uu-nueva-etapa_0_rka7ze-UM.html (дата обращения: 11.10. 2018). 